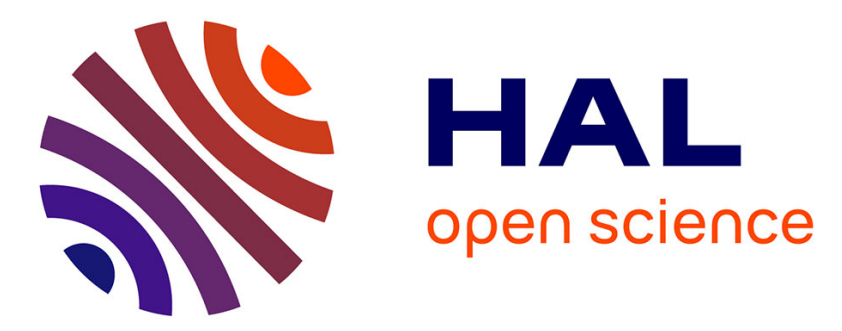

\title{
Disoxaril mutants of Coxsackievirus B1: phenotypic characteristics and analysis of the target VP1 gene.
}

Ivanka Nikolova, Angel S Galabov, Rumena Petkova, Stoyan Chakarov, Boris

Atanasov

\section{- To cite this version:}

Ivanka Nikolova, Angel S Galabov, Rumena Petkova, Stoyan Chakarov, Boris Atanasov. Disoxaril mutants of Coxsackievirus B1: phenotypic characteristics and analysis of the target VP1 gene.. Zeitschrift fur Naturforschung C, 2011, 66 (11-12), pp.627-636. 10.1515/znc-2011-11-1213 . pasteur-00708571

\section{HAL Id: pasteur-00708571 \\ https://hal-riip.archives-ouvertes.fr/pasteur-00708571}

Submitted on 15 Jun 2012

HAL is a multi-disciplinary open access archive for the deposit and dissemination of scientific research documents, whether they are published or not. The documents may come from teaching and research institutions in France or abroad, or from public or private research centers.
L'archive ouverte pluridisciplinaire HAL, est destinée au dépôt et à la diffusion de documents scientifiques de niveau recherche, publiés ou non, émanant des établissements d'enseignement et de recherche français ou étrangers, des laboratoires publics ou privés. 


\title{
Disoxaril Mutants of Coxsackievirus B1: Phenotypic Characteristics and Analysis of the Target VP1 Gene
}

\author{
Ivanka Nikolova ${ }^{a}$, Angel S. Galabov ${ }^{\mathrm{a}, *}$, Rumena Petkova ${ }^{\mathrm{b}}$, Stoyan Chakarov, \\ and Boris Atanasov ${ }^{\mathrm{d}}$ \\ a The Stephan Angeloff Institute of Microbiology, Bulgarian Academy of Sciences, \\ 26, Georgi Bonchev Street, 1113 Sofia, Bulgaria. Fax: +359-2/870 0109 . \\ E-mail: galabov@microbio.bas.bg \\ b Scientific Technological Service, Ltd., Sofia, Bulgaria \\ c Department of Biochemistry, Faculty of Biology, Sofia University, Sofia, Bulgaria \\ d Institute of Organic Chemistry with Centre of Phytochemistry, \\ Bulgarian Academy of Sciences, Sofia, Bulgaria \\ * Author for correspondence and reprint requests \\ Z. Naturforsch. 66c, 627-636 (2011); received January 7/August 24, 2011
}

Disoxaril inhibits enterovirus replication by binding to the hydrophobic pocket within the VP1 coat protein, thus stabilizing the virion and blocking its uncoating. Disoxaril-resistant (RES) mutants of the Coxsackievirus B1 (CVB1/RES) were derived from the wild disoxaril-sensitive (SOF) strain (CVB1/SOF) using a selection approach. A disoxaril-dependent (DEP) mutant (CVB1/DEP) was obtained following nine consecutive passages of the disoxaril-resistant mutant in the presence of disoxaril. Phenotypic characteristics of the disoxaril mutants were investigated. A timing-of-addition study of the CVB1/DEP replication demonstrated that in the absence of disoxaril the virus particle assembly stopped. VP1 RNA sequences of disoxaril mutants were compared with the existing Gen Bank CVB1 reference structure. The amino acid sequence of a large VP1 196-258 peptide (disoxaril-binding region) of CVB1/RES was significantly different from that of the CVB1/SOF. Crucially important changes in CVB1/RES were two point mutations, M213H and F237L, both in the ligand-binding pocket. The sequence analysis of the CVB1/DEP showed some reversion to CVB1/SOF. The amino acid sequences of the three VP1 proteins are presented.

Key words: Coxsackievirus B1, Disoxaril Mutants, VP1 Amino Acid Sequence

\section{Introduction}

A number of studies have shown that the lack of success in the development of an effective chemotherapy of enteroviral infections is due to the extraordinarily fast development of drug resistance to each of the known specific picornaviral replication inhibitors - protein ligands. This phenomenon is due to the extraordinarily high mutation rate $\left(10^{-3}-10^{-4}\right)$ (Richards and Ehrenfeld, 1990) based on the great infidelity of the viral RNA-dependent RNA polymerase thus giving rise to a viral population of billions of quasi(pseudo-)species. One mutation per each newly synthesized molecule of poliovirus RNA has been established (Agol, 2006). This can explain the vast diversity of clinical manifestations caused by almost every one of the members of the Enterovirus genus.

Twenty years ago it was found that WIN compounds (such as arildone, disoxaril, pleconaril) inhibit the virion uncoating process (Fox et al., 1986). The direct crystal X-ray analysis of virusinhibitor complexes showed that the primary target structure of this action is the hydrophobic pocket beneath the "canyon" on the VP1 protein (Rossmann, 1989). WIN compounds inserted into a cleft formed by a twisted $\beta$-sheet increase the structural rigidity of the VP1 subunit thus preventing virus uncoating.

Disoxaril is a typical representative of the WIN compounds - a highly effective inhibitor of a broad spectrum of entero- and rhinovirus serotypes. Enterovirus resistance to disoxaril has been established initially with poliovirus type $3 /$ Sabin (Mosser et al., 1994). Later this resistance was observed in Coxsackievirus B3 (CVB3) to another WIN compound, pleconaril (Groarke and Pevear, 1999).

In our previous research (Nikolova and Galabov, 2003) we have demonstrated the development of resistance to disoxaril during treat- 
ment of experimental Coxsackievirus B1 (CVB1) infection in newborn mice. Only three passages of the wild disoxaril-sensitive strain of CVB1 (CVB1/SOF) in FL cell cultures in the presence of disoxaril were sufficient for the development of the disoxaril-resistant Coxsackievirus B1 mutant (CVB1/RES). The in vivo and in vitro generated disoxaril-resistant CVB1 mutants demonstrated almost identical phenotypic characteristics. We have also shown that nine consecutive passages of the CVB1/RES in FL cells in the presence of disoxaril gave rise to a disoxaril-dependent mutant (CVB1/DEP) (Nikolova and Galabov, 2002). An analogous phenomenon was observed in a rhinovirus model (Wang et al., 1998; Lee and Wang, 2003).

The main goal of this study was to clarify the molecular basis of the antiviral effect of disoxaril targeting the CVB1 VP1 protein by comparing phenotypic and genotypic characteristics of the wild strain (disoxaril-sensitive), and disoxaril-resistant and disoxaril-dependent mutants, respectively.

\section{Material and Methods}

\section{Virus, cells, and infectious virus assay}

The disoxaril-sensitive strain Coxsackievirus B1 (Connecticut 5) (CVB1/SOF) was obtained from the collection of the Stephan Angeloff Institute of Microbiology, Bulgarian Academy of Sciences, Sofia, Bulgaria. It was grown in monolayer FL cells on purified plaque with an infectious titer of $9 \cdot 10^{7} \mathrm{PFU} / \mathrm{ml}$.

FL monolayer cell cultures were grown in Costar (Corning, NY, USA) 96- or 24-well plates at $5 \% \mathrm{CO}_{2}$ or in capped $20-\mathrm{ml}$ scintillation glass vials in Dulbecco's minimal essential medium (DMEM) (Gibco BRL, Paisley, UK) supplemented with $5 \%$ fetal bovine serum (Gibco BRL), 10 mм HEPES buffer (Merck, Darmstadt, Germany), and antibiotics (100 IU/ml penicillin, $100 \mu \mathrm{g} / \mathrm{ml}$ streptomycin). The maintenance solution was $0.5 \%$ fetal bovine serum (Gibco BRL) and antibiotics in DMEM.

The infection titer of the stock viruses was determined in parallel by the endpoint dilution method in FL cells in 96-well microplates and by the plaque technique using monolayer cultures in 20-ml scintillation glass vials or 24-well microplates. The agar overlay ( 1 or $0.8 \mathrm{ml}$ for scintillation vials and 24-well microplates, respectively) consisted of $1 \%$ purified agar in Eagle's MEM (Gibco BRL) supplemented with $10 \%$ heated calf serum, $1.65 \mu \mathrm{g} / \mathrm{ml}$ sodium bicarbonate, and antibiotics. Following a 48 -h incubation at $37^{\circ} \mathrm{C}$, a second overlay [ $1.5 \%$ agar with $0.02 \%$ neutral red (Gibco BRL) in physiological saline] was added, and vials/plates were kept at room temperature.

\section{Disoxaril-resistant and disoxaril-dependent mutants of Coxsackievirus B1}

5-[7-[4(4,5-Dihydro-2-oxazolyl)phenoxy]heptyl]-methyl-isoxazole (disoxaril, WIN 51 711) was supplied by Sanofi Winthrop, Inc. (Malverne, PA, USA) and was used without additional purification. Drug-resistant progeny (CVB1/RES) was developed after three consecutive passages of the wild CVB1/SOF in FL cells in the presence of $30 \mu \mathrm{m}$ disoxaril. In parallel, aliquots of the same virus were cultivated in the absence of disoxaril and served as controls. After $48 \mathrm{~h}$ of cultivation (until a cytopathic effect of a complete confluence was achieved) the virus was harvested following triple freezing and thawing of the infected cell cultures. Following the plaque purification procedure, the titer of the resistant progeny was determined by the plaque inhibition test in the presence and in the absence of disoxaril. The $50 \%$ minimal inhibitory concentrations $\left(\mathrm{MIC}_{50}\right)$ were evaluated.

Nine consecutive passages of CVB1/RES in FL cells in the presence of $30 \mu \mathrm{M}$ disoxaril resulted in selection of a disoxaril-dependent mutant (CVB1/ DEP). Aliquots of the same virus cultivated in the absence of disoxaril served as controls $(\Delta \operatorname{logs}=$ $8 \mathrm{log}$ ). Following the plaque purification procedure, the titer of the disoxaril-dependent progeny was measured by the plaque inhibition test in the presence and in the absence of disoxaril and $\mathrm{MIC}_{50}$ values were determined.

\section{Thermal sensitivity test}

Samples of the wild CVB1/SOF and the mutants CVB1/RES and CVB1/DEP, containing $10^{7.3} \mathrm{CCID}_{50} / \mathrm{ml}$ ( $50 \%$ cell culture infectious dose) each in $1 \mathrm{ml}$ of DMEM with $0.5 \%$ heated calf serum, were placed in a waterbath at 46,50 , and $54{ }^{\circ} \mathrm{C}$, respectively. Disoxaril $(30 \mu \mathrm{M})$ was added to the medium in experiments with CVB1/DEP. Aliquots were removed after various periods of time and cooled immediately in an icebath. The 
virus assay was carried out by the endpoint dilution method in monolayer FL cells in 96-well microplates.

\section{Timing-of-addition study}

The one-step growth cycle experiment of the wild $\mathrm{CVB} 1 / \mathrm{SOF}$ and the CVB1/DEP was performed in FL monolayer cell cultures grown in $20-\mathrm{ml}$ scintillation glass vials (pre-washed in Hanks saline, $\mathrm{pH} 7.2$ ) and virus-inoculated at multiplicity of infection (MOI) of 50 by 60 -min adsorption at $4{ }^{\circ} \mathrm{C}$. Infected cultures were triple washed with Hanks saline $(\mathrm{pH} 7.2)$, and $30 \mu \mathrm{M}$ disoxaril was added to the maintenance medium at time 0 and every hour for $6 \mathrm{~h}$ after viral adsorption. Viral samples were collected after 3, 4, 6 , and $9 \mathrm{~h}$, frozen, and frozen-thawed three times. The infectious virus was assayed using the endpoint dilution method in FL cell cultures in 96well microplates in the presence and absence of $30 \mu \mathrm{m}$ disoxaril.

\section{Testing for pathogenicity in mice}

Groups of 17-23 newborn ( $24 \mathrm{~h}$ ) mice were inoculated subcutaneously with the plaque-purified CBV1 wild strain or its disoxaril mutants (suspended in PBS) at a dose range of approximately $100,10,1,0.1$, and $0.01 \mathrm{LD}_{50}$ per mouse (inocula of $0.02 \mathrm{ml}$ ). The infectious titers of stock viruses as assayed in mice were as follows: CVB1/SOF, $10^{4.9} \mathrm{LD}_{50} / 0.02 \mathrm{ml}$; CVB1/RES, $10^{4.9} \mathrm{LD}_{50} / 0.02 \mathrm{ml}$; and CVB1/DEP, $10^{4.7} \mathrm{LD}_{50} / 0.02 \mathrm{ml}$. Disoxaril was administered subcutaneously in the course of a 10 -d treatment, with a single daily dose of $25 \mathrm{mg} /$ $\mathrm{kg}$ body weight $(0.05 \mathrm{ml} / \mathrm{mouse})$, started immediately after virus inoculation. Disoxaril-treated groups of animals and groups of simultaneously infected animals not receiving disoxaril were monitored daily for survival over $14 \mathrm{~d}$ post virus inoculation, and the cumulative mortality rate (percentage) and mean survival time were evaluated.

\section{RNA extraction}

Total RNA was extracted from plaque-purified wild CVB1/SOF and the disoxaril mutants CVB1/ RES and CVB1/DEP using the total RNA isolation system (Promega Corp., Madison, WI, USA) according to the manufacturer's instructions. The
RNA pellets were air-dried in an RNAase-free environment, and RNA was dissolved in $10 \mu \mathrm{l}$ diethylpyrocarbonate-treated water at $-20^{\circ} \mathrm{C}$.

\section{Reverse transcriptase-polymerase chain reaction (RT-PCR) amplification}

The region of the viral RNA encoding the st ructural protein VP1 of the wild CVB1 strain and its disoxaril mutants was amplified by RTPCR. The primer pairs utilized for RT-PCR were: VP1-1U, 5'GGCCCAGTGGAAGAATCGGT3', andVP1-1L, 5'ACACTGGTAGCGGTACTGG3'; VP1-2U, 5'GAGAAGGGCTACGCAGAGTG3', and VP1-2L, 5'GCCGTAAACCCCATTCCTAG3'; VP1-3U, 5'TTTTGGACAGAGGGGAAGC3', and VP1-3L, 5'TGTGGTAATGTTTGAGCGCG3'; VP1-4U, 5'GGCCCAGTGGAAGAATCGGT3', and VP1-4L, 5'GTGGTGACTCCTGTTGGGTT3' (Iizuka et al., 1987). RT was conducted with $2 \mu \mathrm{g}$ RNA in a final reaction volume of $25 \mu \mathrm{l}$. RNA and primers were heated to $70{ }^{\circ} \mathrm{C}$ for $5 \mathrm{~min}$, followed by addition of the RT reaction components. The reaction was incubated at $42{ }^{\circ} \mathrm{C}$ for $1 \mathrm{~h}$. Two microlitres of the RT reaction mixture were subjected to PCR amplification using TaqDNAPol (Roche Applied Science, Indianapolis, IN, USA) according to the manufacturer's protocol. The amplification reaction was performed in 30 cycles, each cycle consisting of $40 \mathrm{~s}$ at $72{ }^{\circ} \mathrm{C}, 60 \mathrm{~s}$ at $45^{\circ} \mathrm{C}, 60 \mathrm{~s}$ at $95^{\circ} \mathrm{C}$, and the mixture was then cooled at $10^{\circ} \mathrm{C}$ for $2 \mathrm{~min}$. The PCR product was determined in $1.5 \%$ agarose gel by ethidium bromide staining.

\section{VP1 gene sequencing}

VP1 genes of the wild CVB1 and its disoxaril mutants were sequenced by the Sanger's dideoxy method (Sanger et al., 1977) with the Autoread Sequencing Kit (Pharmacia, New Brunswick, NJ, USA) and the ALF DNA Sequencer Unit (Pharmacia) in the Pasteur Institute, Paris, France. Sequence comparison of the mutants was done by BLAST ${ }^{\circledR}$ from NCBI (World Database) (Altschul et al., 1997).

\section{Statistics}

Differences between groups were analysed for significance using One-Way ANOVA test and Student's $t$-test. 

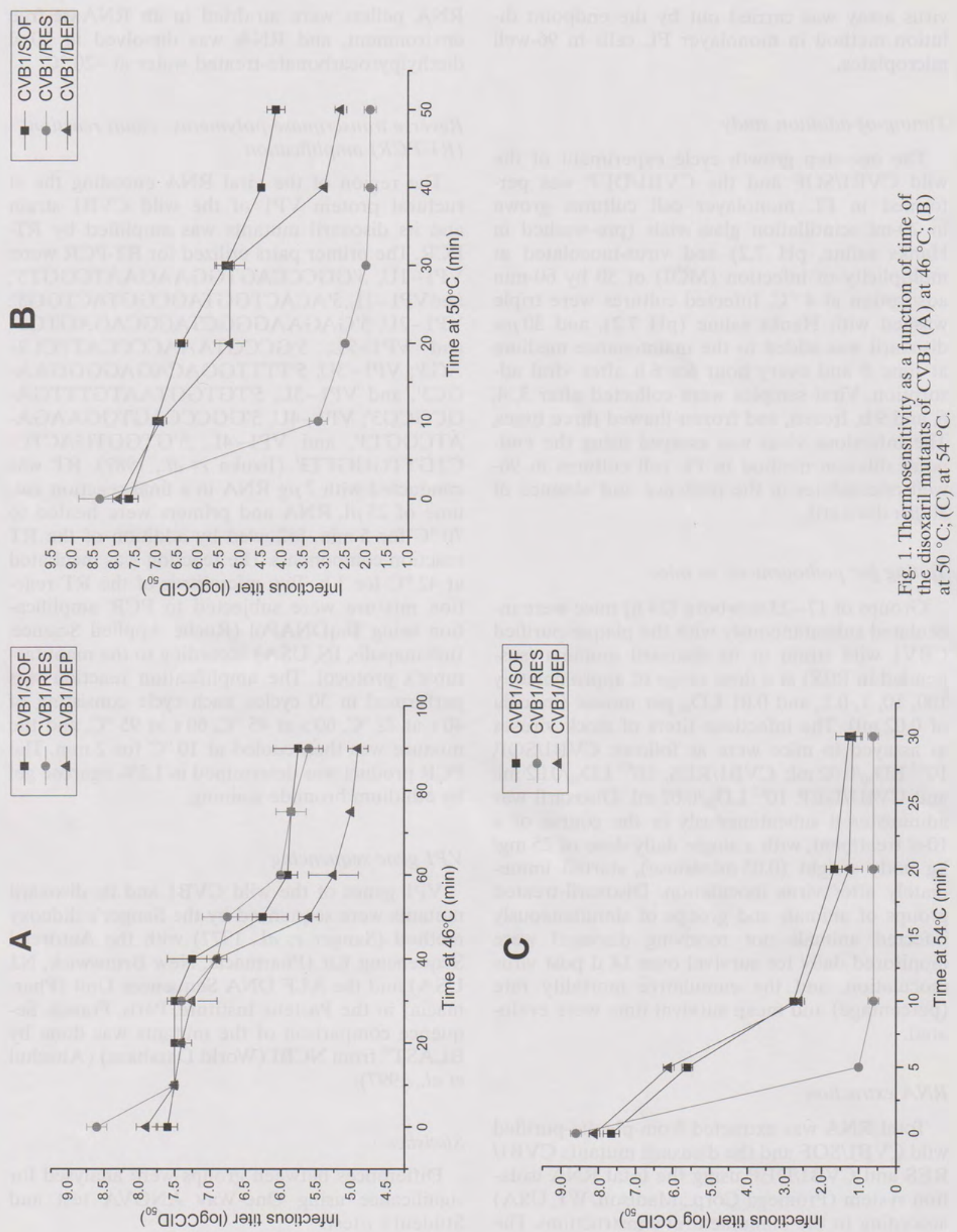
Table I. Pathogenicity for newborn mice of the disoxaril-sensitive wild strain of CVB1 (CVB1/SOF) and the disoxaril-dependent mutant of CVB1 (CVB1/DEP) in the absence $(-\mathrm{WIN})$ and presence $(+\mathrm{WIN})$ of disoxaril.

\begin{tabular}{|c|c|c|c|c|}
\hline Virus & $\begin{array}{c}\mathrm{LD}_{50}{ }^{\mathrm{a}} \text { per } \\
\text { mouse }\end{array}$ & $\mathrm{N}^{\mathrm{b}}$ & $\begin{array}{c}\text { Mortality } \\
(\%)\end{array}$ & $\begin{array}{c}\text { MST } \pm \text { SEM }^{c} \\
{[\mathrm{~d}]}\end{array}$ \\
\hline \multirow{5}{*}{$\begin{array}{l}\text { CVB1/SOF } \\
(- \text { WIN })\end{array}$} & 70.1 & 17 & 100 & $4.4 * * * \pm 0.035$ \\
\hline & 7.1 & 18 & 77.5 & $7.6 \pm 0.11$ \\
\hline & 0.7 & 21 & 37.5 & $10.2 \pm 0.14$ \\
\hline & 0.07 & 20 & 17.5 & $12.4 \pm 0.32$ \\
\hline & 0.007 & 23 & 0 & 14.0 \\
\hline \multirow{5}{*}{$\begin{array}{l}\text { CVB1/SOF } \\
(+ \text { WIN })\end{array}$} & 82.0 & 16 & 100 & $6.0 \pm 0.071$ \\
\hline & 8.2 & 19 & 68.3 & $8.4 \pm 0.18$ \\
\hline & 0.82 & 18 & 42.2 & 10.0 \\
\hline & 0.082 & 17 & 13 & $12.9 \pm 0.067$ \\
\hline & 0.0082 & 21 & 0 & 14.0 \\
\hline \multirow{6}{*}{$\begin{array}{l}\text { CVB1/DEP } \\
(- \text { WIN) }\end{array}$} & 333.3 & 20 & 100 & $6.7 * * * \pm 0.035$ \\
\hline & 33.3 & 19 & 68.3 & $7.2^{++} \pm 0.18$ \\
\hline & 3.3 & 17 & 53.7 & $10.6 \pm 0.28$ \\
\hline & 0.33 & 19 & 40.0 & $10.9 \pm 0.18$ \\
\hline & 0.033 & 21 & 19.1 & $12.2 \pm 0.18$ \\
\hline & 0.003 & 22 & 0 & 14.0 \\
\hline \multirow{5}{*}{$\begin{array}{l}\text { CVB1/DEP } \\
(+ \text { WIN })\end{array}$} & 94.0 & 21 & 100 & $4.3 \pm 0.035$ \\
\hline & 9.4 & 20 & 78.4 & $6.5 \pm 0.21$ \\
\hline & 0.94 & 19 & 36.6 & $10.9 \pm 0.035$ \\
\hline & 0.094 & 17 & 22.7 & $12.1 \pm 0.14$ \\
\hline & 0.009 & 19 & 0 & 14.0 \\
\hline
\end{tabular}

a $50 \%$ lethal dose; banimal number per experimental group; 'MST, mean survival time; SEM, standard error of the mean.

Comparison between MST values through the OneWay ANOVA test:

* indicates significant difference between CVB1/SOF $(-\mathrm{WIN})$ at $70.1 \mathrm{LD}_{50}$ vs. CVB1/SOF $(+\mathrm{WIN})$ at 82.0 $\mathrm{LD}_{50} ; \mathrm{CVB} 1 / \mathrm{DEP}(-\mathrm{WIN})$ at $333.3 \mathrm{LD}_{50}$ vs. CVB1/ DEP (+WIN) at 94.0 LD $_{50}$; CVB1/DEP (-WIN) at 3.3 $\mathrm{LD}_{50}$ vs. CVB1/DEP (+WIN) at $9.4 \mathrm{LD}_{50}$;

indicates significant difference between CVB1/DEP (WIN) at $33.3 \mathrm{LD}_{50}$ vs. CVB1/DEP (+WIN) at $94.0 \mathrm{LD}_{50}$. * $p<0.05 ; * *,++p<0.01 ; * * * p<0.0001$.

\section{Results}

\section{Thermosensitivity}

The thermosensitivity of the disoxaril-dependent mutant (CVB1/DEP), the disoxaril-resistant mutant (CVB1/RES) isolated from cell culture, and the disoxaril-sensitive strain (CVB1/SOF) was investigated at $46^{\circ} \mathrm{C}, 50^{\circ} \mathrm{C}$, and $54^{\circ} \mathrm{C}$ (Fig. 1). The effective time $\left(\mathrm{ET}_{50}\right)$ (time within which the virus titer is reduced by $50 \%$ ) was calculated for each mutant. $\mathrm{ET}_{50}$ of the wild, disoxaril-sensitive strain was $48 \mathrm{~min} 7 \mathrm{~s}$ at $46{ }^{\circ} \mathrm{C}, 27 \mathrm{~min} 1 \mathrm{~s}$ at $50{ }^{\circ} \mathrm{C}$, and $7 \mathrm{~min}$ at $54^{\circ} \mathrm{C} . \mathrm{ET}_{50}$ of the disoxaril-resistant mutant was $46 \min 2 \mathrm{~s}$ at $46{ }^{\circ} \mathrm{C}, 6 \mathrm{~min}$ at $50{ }^{\circ} \mathrm{C}$, and $3 \mathrm{~min} 7 \mathrm{~s}$ at $54{ }^{\circ} \mathrm{C}$, and those of the disoxaril-dependent mutant were $46 \mathrm{~min} 1 \mathrm{~s}$ at $46^{\circ} \mathrm{C}$, $23 \mathrm{~min} 3 \mathrm{~s}$ at $50{ }^{\circ} \mathrm{C}$, and $7 \mathrm{~min} 3 \mathrm{~s}$ at $54{ }^{\circ} \mathrm{C}$. While the thermosensitivity of the disoxaril-dependent mutant was close to that of the wild disoxaril-sensitive CVB1 strain, the disoxaril-resistant mutant showed increased thermosensitivity.

\section{Pathogenicity in mice}

In a mouse model, the pathogenicity of the disoxaril-resistant mutant (CVB1/RES) was previously found to be slightly higher than that of the disoxaril-sensitive wild strain (CVB1/SOF) (especially at lower virus inocula of 0.1 or 0.01 $\mathrm{LD}_{50}$ ) (Nikolova and Galabov, 2003). We now investigated the specific pathogenicity in mice of CVB1/DEP and CVB1/SOF in mice in the presence and absence of disoxaril. As seen in Table I, CVB1/DEP in the disoxaril-treated mice manifested pathogenicity analogous to that of CVB1/ SOF in the untreated mice (placebo group). The disoxaril treatment exerted a modest protective effect in mice infected with CVB1/SOF, which was manifested as a lengthening of the mean survival time (MST) by only 1.6 days at $70-80$ $\mathrm{LD}_{50}$ and 0.8 days at $7-8 \mathrm{LD}_{50}$. In $\mathrm{CVB} 1 / \mathrm{DEP}$ infected mice the dioxaril treatment resulted in a

Table II. Phenotypic characteristics of CVB1 wild strain and its disoxaril mutants.

\begin{tabular}{|c|c|c|c|c|c|}
\hline Virus & $\begin{array}{l}\mathrm{MIC}_{50} \\
{[\mu \mathrm{mol} / 1]}\end{array}$ & $\begin{array}{l}\text { Plaque diameter } \\
{[\mathrm{mm}]}\end{array}$ & Plaque shape & $\begin{array}{l}\text { Stability at } 50^{\circ} \mathrm{C} \text {, } \\
\mathrm{ET}_{50}{ }^{a}[\mathrm{~min}]\end{array}$ & $\begin{array}{l}\text { Pathogenicity for } \\
\text { mice }\end{array}$ \\
\hline CVB1/SOF & 0.84 & $0.9 \pm 0.3$ & round & 31 & normal \\
\hline CVB1/RES & $>30.0$ & $1.9 \pm 0.1^{*}$ & irregular & 7 & slightly increased \\
\hline CVB1/DEP & - & $1.9 \pm 0.1$ & irregular & 23 & normal \\
\hline
\end{tabular}

a $\mathrm{ET}_{50}$, effective time $50 \%$ : the time (in minutes) necessary for a $50 \%$ reduction of the infectious virus titer.

* $p<0.001$ for CVB1/RES vs. CVB1/SOF mutants, Student's $t$-test. 
A

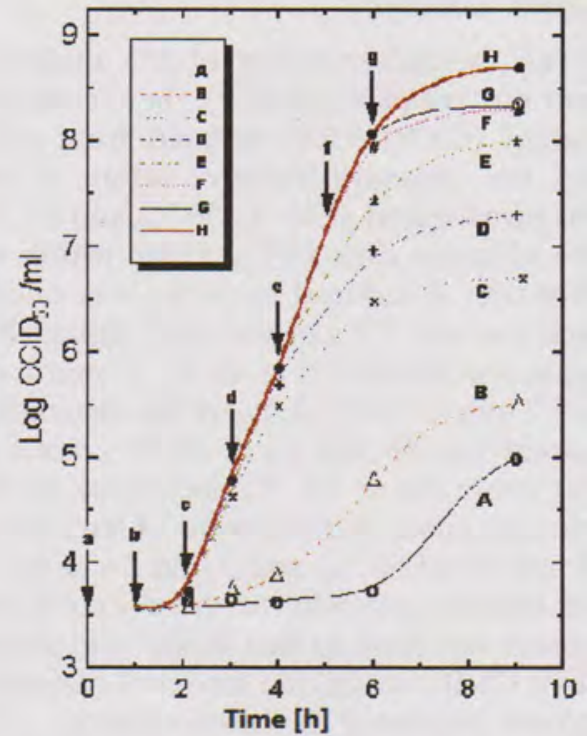

B

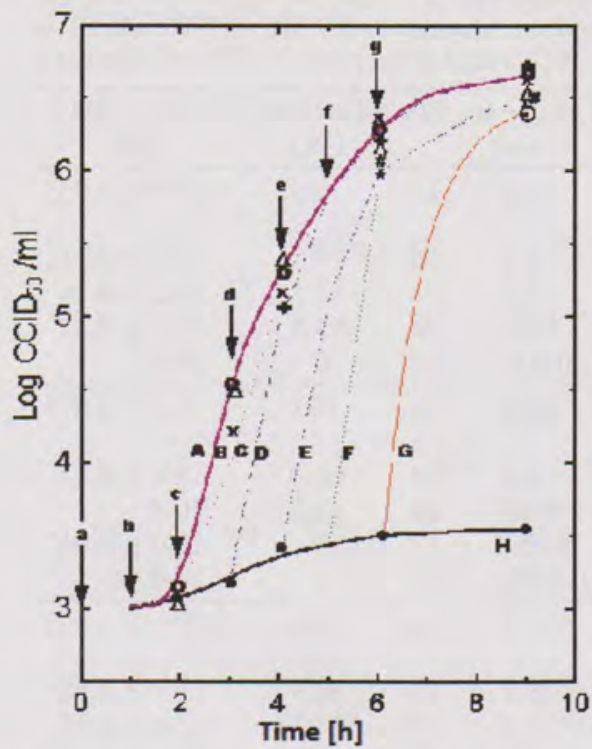

Fig. 2. Effect of disoxaril on replication of (A) the wild, disoxaril-sensitive CVB1 (CVB1/SOF) and (B) the disoxaril-dependent mutant of CVB1 (CVB1/DEP) in FL cells $\left(5 \cdot 10^{5}\right.$ cells/vial), using the one-step growth cycle experimental setup (MOI of 50). Disoxaril $(30 \mu \mathrm{mol})$ was added to the maintenance medium at the times indicated by arrows and was present until the end of the growth cycle: A-G, disoxaril added immediately, $1 \mathrm{~h}, 2 \mathrm{~h}, 3 \mathrm{~h}, 4 \mathrm{~h}$ or $5 \mathrm{~h}$, respectively, after virus inoculation; $\mathrm{H}$, control (without disoxaril).

pronounced shortening of the MST as compared to the placebo group, i.e. by $2.4-2.9$ days at 94 $\mathrm{LD}_{50}$, and by 4.1 days at $9.4 \mathrm{LD}_{50}$. In addition, the lethality rate was increased by 25 to $32 \%$. These data are in agreement with the characteristic drug dependence.

Table II summarizes the data of our present and previous studies on the phenotypic characteristics of disoxaril mutants.

\section{Timing-of-addition study}

To determine the effect of disoxaril on the production of infectious virions during the replication cycle of CVB1/SOF and CVB1/DEP we used the one-step viral growth cycle experimental setup at MOI $\sim 50$. The analysis showed that even the late addition of the compound to the disoxaril-dependent mutant (i.e. during the exponential phase: at the $5^{\text {th }}$ to $6^{\text {th }} \mathrm{h}$ after virus inoculation) provided full production of infectious virions at the end of the one-step cycle, i.e. at the $9^{\text {th }}$ hour (Fig. 2A).

The above findings are in contrast with the observed effect of disoxaril on the replication of the disoxaril-sensitive wild strain in a similar setup. In this case, the inhibitory effect of the compound strongly depended on the exact moment of addition during the latent period $\left(0 \sim 3^{\text {rd }}\right.$ hour after virus inoculation). Furthermore, this effect was strongest when the compound was added immediately after virus adsorption. Adding the compound later on during the exponential phase had no significant effect on the production of matured virions (Fig. 2B).

\section{VP1 gene sequencing of wild strain and its mutants}

DNA fragments containing the complete VP1 sequence of wild CVB1/SOF and both disoxaril mutants were generated by RT-PCR. The degree of identity between the sequences of the whole genome of CVB1/SOF as compared to the reference CVB1/REF (Iizuka et al., 1987) varied between $77 \%$ and $82 \%$. A constant specific feature was observed in all DNA fragments of CVB1/ RES and CVB1/DEP when compared to the reference sequence, and the sequence of CVB1/ SOF was the deletion of a nucleotide TTG /in- 


\begin{tabular}{|c|c|c|c|c|c|}
\hline & 10 & 20 & 30 & 40 & 50 \\
\hline 1 CVB1/REF & GPVEESVERA & MVRVADTVSS & KPTNSESIPA & LTAAETGHTS & QVVPSDTMQT \\
\hline CVB1/SOF & ExQx & $x N=x x x x x I x$ & $x--x=-L--D$ & $I-V---x Y-F$ & 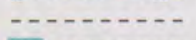 \\
\hline CVB1/RES & xxPxxSPW & KN-WPSGRIG & G-VEESVAxx & $\mathrm{xxxxxx}-\mathrm{x}-$ & GP- $x x \times x \times x x$ \\
\hline CVB1/DEP & $D-x$ & $\mathrm{xN}-\cdots-\mathrm{M}-\mathrm{R}$ & $-----L-\cdots$ & $-\cdots-\cdots$ & $\ldots$ \\
\hline
\end{tabular}
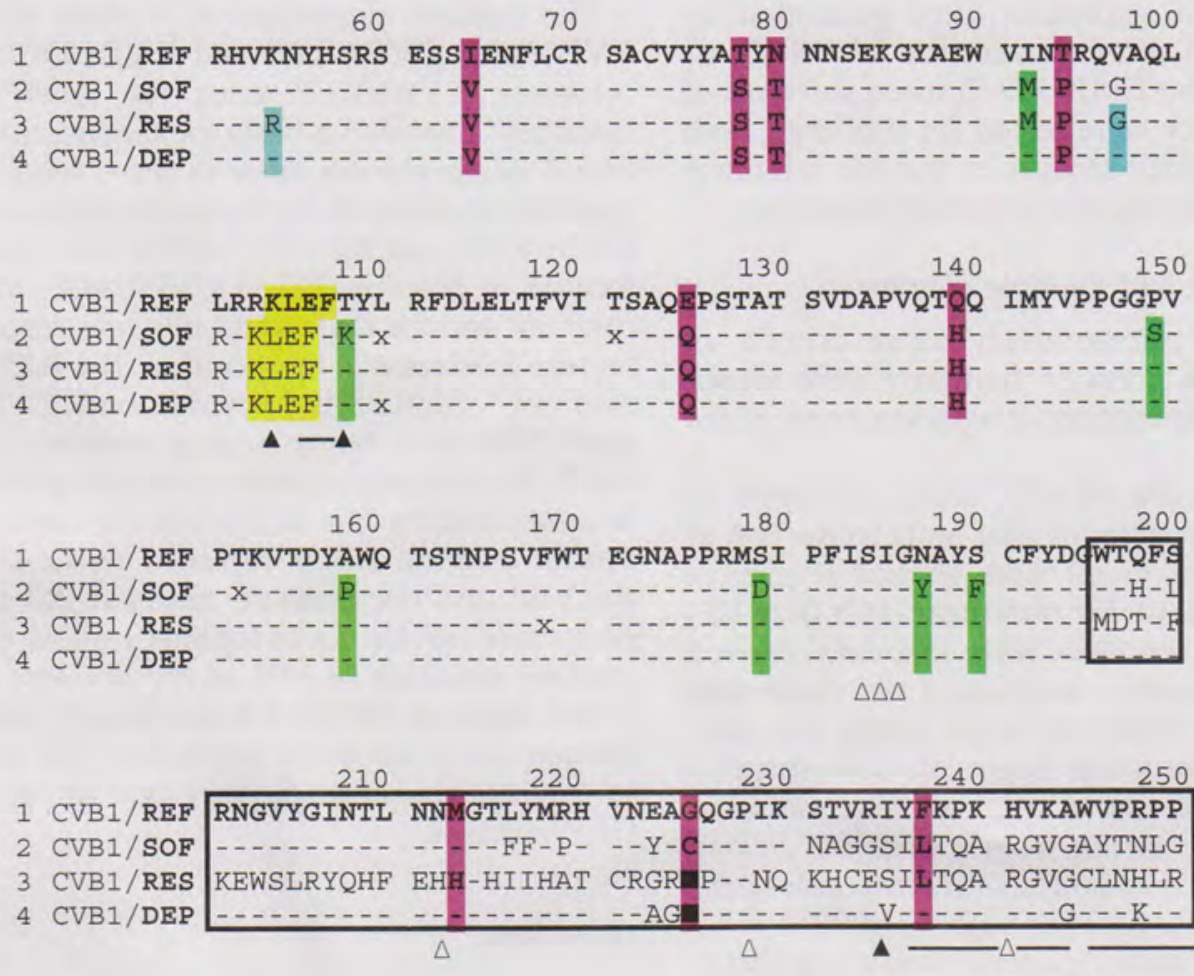

\begin{tabular}{|c|c|c|c|c|}
\hline & 260 & 270 & 280 & 290 \\
\hline 1 CVB1/REF & RLCQYEKQ $\mathrm{kN}$ & VNFNPTGVTT & TRSNITTT-- & --------- \\
\hline CVB1/SOF & FALFK-K- & $\overline{R Y}-\bar{K}-\overline{N X} G G X$ & xPxxxxxxTP & XXFFF $x \times x P F \quad x$ \\
\hline CVB1/RES & $---\mathrm{VKN}$ & RxLX-PPGGG & $F \times P x x \times F \times x K$ & XXPRFFL $x x-x$ \\
\hline CVB1/DEP & $\mathrm{R}--\mathrm{xFKN}$ & -T----GGx & 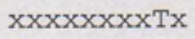 & $\mathrm{xxxxx \times x} \times \mathrm{xx}$ \\
\hline
\end{tabular}

Fig. 3. Alignment and inter-correlation of the CVB1 VP1 translated sequences (CVB1/SOF, CVB1/RES, and CVB1/ DEP) with that of CVB3 VP1 CVB1/REF: - deletion; $x$, no read AA position; $\triangle$, AA essential for ligand pocket ("canyon"); $\boldsymbol{\Delta}-\boldsymbol{\Delta}, \mathrm{AA}$ on the internal side of the ligand pocket; $\square, \mathrm{AA}$ in ligand pocket and its close surrounding. Marked in colour: pink, CVB1/SOF specific mutants; green, CVB1/SOF mutants reverted to CVB1/REF in CVB1/ RES and CVB1/DEP mutants; blue, CVB1/RES mutants reverted to CVB1/REF. AA, amino acid.

sertion of a nucleotides TTT at the same position in relation to the reference sequence and that of CVB1/SOF (ntt 2749-2751 from M16560/ ins TTTnt). These changes did not lead to any change of the reading frame and were discovered both in the "forward" and the "reverse" nucleotide sequence. The sequence comparison was performed at the level of the derived amino acid sequences (Fig. 3).

The amino acid sequences of the respective proteins of CVB3 and CVA9 were obtained from the PDB files 1cox.pdb and 1d4m.pdb, respectively (see below). Even though the $\mathrm{X}$ values obtained this way are located mostly at the chains' 
ends, they were made sensible by the following substitutions: X values of VP1 of CVB1/SOF take the respective values of the reference CVB1/REF (Connecticut 5), while the $\mathrm{X}$ values of CVB1/RES and of CVB1/DEP take the respective values of CVB1/SOF. In parallel and independently, the assumed protein sequences were generated by BLAST (NCBI) software with the BLOSUM 62 matrix and by the EMBOSS-Transeq software of EMBL-EBI. They were tested for similarity, both among the obtained sequences and the reference sequence, and among the obtained sequences.

\section{BLAST analysis and multiple alignment}

Due to the comparatively strict criteria of BLAST analysis, areas of similarity were identified mainly in the medium-length segments of the sequences.

According to the BLAST data, a deletion of Leu and an insertion of Phe were observed at the same location in all three studied sequences when compared to the reference (CVB1/REF) sequence. This complies with the data derived from the comparative analysis of the nucleotide sequence of the fragments under study. The comparison of the particular fragments demonstrated a high degree of similarity of all sequences, except for the area starting from approx. the $200^{\text {th }}$ to $240^{\text {th }}$ amino acid residue which corresponds to the ligand-binding site (canyon region) of VP1.

The main sequence differences between CVB1/ REF and any of the other three VP1 proteins are summarized in Table III.
Substantial differences in the VP1 sequences between CVB1/SOF, CVB1/RES, and CVB1/ DEP are observed in amino acid residues 196 to 258 (see Fig. 3). It is remarkable that SOF and DEP mutants have a higher degree of similarity than SOF and RES mutants.

The multiple alignments of all three sequences, CVB1/SOF, CVB1/RES and CVB1/DEP, to the reference CVB1/REF using the „BMC search launcher" provided a basis for fundamentally different interpretation, since in these sequences all gaps are clustered in the ligand-binding site of the CVB1/RES and the CVB1/DEP mutants. Cys is located in position 225 in CVB1/SOF, while the resistant and the dependent mutants, respectively, feature a deletion at this position. The R251 amino acid of CVB1/REF is deleted in both CVB1/SOF and CVB1/RES, but it is again present in CVB1/ DEP. The critically significant Met in position 213 is substituted by His in the resistant mutant, and Phe in position 237 is replaced by Leu in both the wild and the resistant mutants. All analyses performed so far unambiguously show that the primary structure of VP1 of the resistant mutant in the segment $195-258$ is profoundly altered in comparison to all other sequences. The reversion to original sequences is very typical for CVB1/ DEP mutants.

\section{Discussion}

The analysis of the phenotypic markers of the isolated disoxaril mutants showed that the chang-

Table III. Mutations in the genome region encoding the VP1 capsid protein of CVB1/REF, CVB1/SOF, and the mutants CVB1/RES and CVB1/DEP (summarized data).

\begin{tabular}{|c|c|}
\hline $\begin{array}{l}\text { Essential mutations at ligand- } \\
\text { binding box }\end{array}$ & $\begin{array}{l}\text { (REF)S25 (SOF,RES), (REF)P94T(SOF,RES,DEP), (REF)M213H(RES), } \\
\text { (RES)H213M(DEP), (REF)G225C(SOF), (SOF)C225 (RES,DEP), (REF) } \\
\text { F237 L(SOF,RES), (RES)L237F(DEP), (REF)R251 (SOF,RES), (RES) } \\
\text {-251R(DEP). }\end{array}$ \\
\hline SOF-specific mutations & $\begin{array}{l}\text { (REF)S40F(SOF,RES,DEP), (REF)I64 V(SOF,RES,DEP), (REF) } \\
\text { T78 V(SOF,RES,DEP), (REF)N80T(SOF,RES,DEP), (REF) } \\
\text { P94T(SOF,RES,DEP), (REF)E125Q(SOF,RES,DEP), (REF) } \\
\text { Q139H(SOF,RES,DEP). }\end{array}$ \\
\hline SOF reverted to REF in RES/DEP & $\begin{array}{l}\text { M92I, K108T, S149P, P158A, D179S, Y187N, F190S, R261 V, K264N, N266T, } \\
\text { x267G }\end{array}$ \\
\hline DEP reverted to $\mathrm{REF} / \mathrm{SOF}$ & $27,28,41,42,54,97$ \\
\hline SOF reverted to REF & $196,197,200-213,215-222,226,229-234,236-247,249-251$ \\
\hline SOF reverted to REF only in DEP & $216,217,231-234,236-243,245-247,249-253$ \\
\hline
\end{tabular}

- Single point deletion. 
es in the sensitivity to disoxaril (WIN) correlated with the changes of the size and the shape of virus plaques under agar. The plaque diameter of the CVB1/RES and CVB1/DEP mutants was bigger and the shape of the plaques was irregular in comparison with the plaques of the disoxarilsensitive strain (CVB1/SOF).

This marker of the CVB1/RES mutant also correlated with the significant increase in its thermosensitivity. These findings are in agreement with those of Groarke and Pevear (1999) for the thermosensitivity of the pleconaril-resistant mutants of Coxsackievirus B3 isolated in cell culture and with ECHO 9 virus isolated from patients treated with pleconaril. The thermosensitivity at $50{ }^{\circ} \mathrm{C}$ and $54^{\circ} \mathrm{C}$ of $\mathrm{CVB} 1 / \mathrm{DEP}$ was found to be closer to that of the wild disoxaril-sensitive strain (CVB1/SOF). These results are similar to those obtained by Schrom et al. (1982) with arildone mutants of poliovirus.

It is well known that the marker $\mathrm{T}_{50^{\circ} \mathrm{C}}$ is related to the stability of virions which in the enteroviruses is to a large extent determined by the VP1 integrity. The ligand pocket cavity of the disoxaril-resistant mutant (CVB1/RES) has such a shape that it prevents the binding of palmitate or disoxaril. This compromises the virions' stability towards drug (WIN) treatment. In the case of dependent mutants, the presence of such an inhibitor in the cell culture medium protects them from thermoinactivation. Mosser and Rueckert (1993) found that the absence of disoxaril in the medium resulted in extreme thermolability of the disoxaril-dependent mutant of poliovirus 3/Sabin strain even at $37^{\circ} \mathrm{C}$.

Differences between CVB1/RES and CVB1/ DEP were also observed in the marker pathogenicity for mice. In contrast to the increased pathogenicity noted for CVB1/RES (Nikolova and Galabov, 2003), CVB1/DEP pathogenicity was strongly dependent on the presence of disoxaril. On one hand, an almost full similarity was established between the pathogenicity found in CVB1/DEP in the presence of disoxaril and in CVB1/SOF in the absence of disoxaril. On the other hand, a considerably stronger decrease in the pathogenicity of CVB1/ DEP in the absence of disoxaril, as compared to the protective effect of the compound on CVB1/ SOF, was found. This data correlates well with the results from the cell culture experiments.

Enteroviruses have a palmitate molecule in the VP1 pocket (therefore also named "pocket ligand"), because of the hydrophobic nature of the central cavity of the pocket and the polar environment at one of its ends. It is released in the initial step of virus entry in the host cell thus destabilizing the virion. WIN compounds can replace the pocket ligand in the hydrophobic pocket, which leads to stabilization of the virus capsid and embarrassed disassembly of the virions in the cell (Muckelbauer et al., 1995; Hendry et al., 1999; Xiao et al., 2005).

The analysis of the results from the timingof-addition study following the one-step virus growth cycle experimental setup with the disoxaril-dependent mutant of CVB1 showed that even the late addition of the compound, i.e. during the exponential phase (5-6 hours after the virus inoculation) guarantees full production of the infectious virions at the end of the one-step cycle. These data lead to the conclusion that structural changes of the capsid protein VP1 in the disoxaril-dependent mutant do not affect the process of uncoating and the following synthesis of viral RNA and proteins. Such changes in VP1 of the disoxaril-dependent mutant appear to affect the stage of the mature virions' assembly only rather than the stage of uncoating and synthesis of viral RNA and proteins. A similar drug-dependent virion assembly process was established in the HRV16 mutant dependent on another WIN compound, WIN 52035 (Wang et al., 1998).

The results with CVB1/SOF show that the inhibitory effect of the compound strongly depends on the time of its addition during the latent period, the data being in compliance with reports in the literature pointing out that disoxaril blocks virus uncoating (Zeichhardt et al., 1987; Diana et al., 1989; Fox et al., 1991).

Our analysis of the primary structure of CVB1 VP1 mutants of the internal segment 196-258 showed that it is highly changed in RES and DEP in comparison to referent REF/SOF structures.

Mosser et al. (1994) found that in the disoxarilresistant mutant of the poliovirus $3 /$ Sabin strain amino acid substitutions were mapped to three distinct loci in VP1 (on the inner capsid surface accompanied probably by substitution at VP4, in the drug-binding site on the $\beta$-barrel, and in the receptor binding site on the canyon edge), while mutations conferring dependence and thermolability occurred in all four capsid proteins (VP1 to VP4).

The CVB1/DEP mutation and mutant behaviour cannot be explained based on the amino 
acid sequence alone. The experimental evidence that CVB1/DEP needs disoxaril to allow virus coating requires further studies of 3D homology modeling to determine the three-dimensional structure of the VP proteins and their intermole-

Agol V. I. (2006), Molecular mechanisms of poliovirus variation and evolution. Curr. Top. Microbiol. Immunol. 299, 211-259.

Altschul S. F., Madden T. L., Schäffer A. A., Zhang J., Zhang Z., Miller W., and Lipman D. J. (1997), Gapped BLAST and PSI-BLAST: a new generation of protein database search programs. Nucleic Acids Res. 25, 3389-3402.

Diana G. D., Pevear D. C., Otto M. J., McKinlay M. A., Rossmann M. C., Smith T., and Badger J. (1989), Inhibitors of viral uncoating. Pharm. Ther. 42, 289-305.

Fox M. P., Otto M. J., and McKinley M. A. (1986), The prevention of poliovirus and rhinovirus uncoating by WIN 51711: a new antiviral drug. Antimicrob. Agents Chemother. 30, 110-116.

Fox M. P., McKinlay M. A., Diana G. D., and Dutko F. J. (1991), Binding affinities of structurally related human rhinovirus capsid-binding compounds are related to their activities against human rhinovirus type 14. Antimicrob. Agents Chemother. 35, 1040-1047.

Groarke J. M. and Pevear D. C. (1999), Attenuated virulence of pleconaril-resistant Coxsackievirus B3 variants. J. Infect. Dis. 179, 1538-1541.

Hendry E., Hatanaka H., Fry E., Smuth M., Tate J., Stanway G., Santti J., Maaronen M., Hyypia T., and Stuart D. (1999), The crystal structure of Coxsackievirus A9: a new insight into the uncoating mechanisms of enteroviruses. Structure 3, 653-667.

Iizuka N., Kuge S., and Nomoto A. (1987), Complete nucleotide sequence of the genome of Coxsackievirus B1. Virology $156,64-73$.

Lee W.-M. and Wang W. (2003), Human rhinovirus type 16: mutant V1210A requires capsid-binding drug for assembly of pentamers to form virions during morphogenesis. J. Virol. 77, 6235-6244.

Mosser A. G. and Rueckert R. R. (1993), WIN 51711-dependent mutants of poliovirus type 3: evidence that virions decay after release from cells unless drug is present. J. Virol. 67, 1246-1254.

Mosser A. G., Sgro J. Y., and Rueckert R. R. (1994), Distribution of drug resistance mutations in type 3 cular contacts between capsomers. Such approach could contribute also to the characterization of CVB1/RES and would clarify the nature of disoxaril-resistance and dependence. Homology modeling studies are already in progress.

poliovirus identifies three regions involved in uncoating functions. J. Virol. 68, 8193-8201.

Muckelbauer J. K., Kremer M., Minor I., Diana G., Dutko J., Groarke J., Pevear C., and Rossmann M. G. (1995), The structure of Coxsackievirus B3 at $\AA$ resolution. Structure (London) 3, 653-666.

Nikolova I. and Galabov A. S. (2002), Isolation of disoxaril-dependent mutant of Coxsackievirus B1. Tenth Congress of the Bulgarian Microbiologists, Plovdiv, October 9-12, 2002. SAIM, Sofia, Vol. I, pp. 332-335.

Nikolova I. and Galabov A. S. (2003), Development of resistance to disoxaril in Coxsackievirus B1 infected newborn mice. Antiviral Res. 60, 35-40.

Richards O. C. and Ehrenfeld E. (1990), Poliovirus RNA replication. Curr. Top. Microbiol. Immunol. 161, 89-121.

Rossmann M. G. (1989), The structure of antiviral agents that inhibit uncoating when complexed with viral capsids. Antiviral Res. 11, 3-14.

Sanger S. A., Nicklen R., and Coulson A. (1977), DNA sequencing with chain-terminating inhibitors. Proc. Natl. Acad. Sci. USA 74, 5463-5467.

Schrom M., Laffin A. J., Evans B., McSharry J. J., and Caliguiri A. L. (1982), Isolation of poliovirus variants resistant to and dependent on arildone. Virology 122, $492-497$.

Wang W., Lee W. M., Mosser A. G., and Rueckert R. R. (1998), WIN 52035-dependent human rhinovirus 16: assembly deficiency caused by mutations near the canyon surface. J. Virol. 72, 1210-1218.

Xiao C., Bator-Kelly C., Rieder E., Chipman P. R., Craig A., Kuhn R. J., Wimmer E., and Rossmann M. G. (2005), The crystal structure of Coxsackievirus A21 and its interaction with ICAM-1. Structure 13, 1019-1033.

Zeichhardt H., Otto M. J., McKinlay M. A., Willingmann P., and Habermehl K. O. (1987), Inhibition of poliovirus uncoating by disoxaril (WIN 51711 ). Virology 160, 281-295. 